\title{
Mia Hall's Decision Making Process in Her Comatose State in Gayle Forman's If I Stay: A Psychoanalytic Study
}

\author{
Chindy Christine \& Dewi Widyastuti \\ chindychristine@gmail.com \& ewi@usd.ac.id \\ Department of English Letters, Universitas Sanata Dharma
}

\begin{abstract}
This undergraduate study discusses a novel written by Gayle Forman entitled If I Stay through the psychoanalytic study. The main character of the novel, Mia Hall, is in a comatose state after she gets an accident with her family. Her parents and her brother do not survive. In this unconscious state, she has to choose one of the two choices whether to stay or to leave. Her decision-making process, which the main character faces, inspires the researcher to study how Mia Hall's unconsciousness is able to influence her decision making. The researcher formulates two problems for this study: (1) how the main character is described in the plot development of the story, and (2) how the decision-making process of the main character is seen in the story.

The analysis produces some results and findings. The first finding is that the main character's traits are family-centered, enthusiastic, loving, and thoughtful. The second result is that the main character's decision making process is a descriptive model of decision making. The reason why she decides to stay in the world is influenced by her identity and the effects of her unconsciousness, in which she still has her grandparents as her family, her dream to become a cellist that she can pursue, and the people surrounding her whom she can share her affection for.
\end{abstract}

Keywords: psychoanalytic study, comatose state, Gayle Forman

\section{Introduction}

Factors of a decision making process come from human minds, which are the conscious and unconscious. In literary studies, those conscious and unconscious minds are analyzed in psychoanalysis. Psychoanalytic reading is an approach of literary study which focuses on the explanations of the growth, development, and structure of human personality (Dobie, 2012: 54) by observing the interaction of conscious and unconscious thoughts in mind (Barry, 2002: 96). Besides the conscious elements which come from the outer and inner self mentioned above, the unconscious things in mind play important roles in someone's decision making. Based on Freudian psychoanalysis theory reviewed by John Feist, the unconscious contains "all those drives, urges, or instincts that are beyond our awareness", and they motivate most of our words, feelings, and actions (Feist, 2006: 24). This study analyzes how the unconscious mind is able to motivate and trigger the main character's decision making process, and one of the ways to observe how unconscious mind can influence someone's decision making is through observing a patient's mind who is in a comatose state.

Feist says the state of being comatose comes from the damage to an area of the 
brain stem and make a person become unconscious. The reason why someone can become unconscious is because the brain stem associates with the unconsciousness in the sense of not being awake (Feist, 2006: 54). Shortly, a comatose state is a state where someone is being unconscious physically and mentally. When people are being in a coma, they are believed to be in the unconscious state (Laureys, 2005: 899). Medically, that person can do nothing. However, their mind does the other way around as it is described in Gayle Forman's If I Stay. Although someone is in a comatose state and physically unconscious, the soul of that person is able to make a decision because of the unconscious that has been formed in the mind.

The main character in If I Stay, Mia Hall, is in this comatose state, and during this state, she has gone through a lot of matters which make her confused about whether to choose to live or to follow her family's path to leave the world. Choosing between life and death is a rarely-found choice in this life reality. Human beings often take this life for granted until sometimes, the struggle to live this life in the best way is barely found.

This study is to point out that characteristics formed in the unconscious mind can influence someone's decision making process in a comatose state as seen in the main character of Gayle Forman's If I Stay. To do so, the psychoanalysis approach is employed to have a better understanding of the matter. Based on the phenomenon above, the researcher proposes two formulations: (1) How is the main character described in the plot development of Gayle Forman's If I Stay?, and (2) How is the decision-making process of the main character seen in Gayle Forman's If I Stay?

\section{The Unconscious}

Peter Barry states that "unconscious is the part of the mind beyond consciousness which nevertheless has a strong influence upon our actions" (2002: 96). Michael Ryan also has his definition of the unconscious that
The unconscious refers to two things in psychology and psychoanalysis. The first derives from its use in recent cognitive psychology, and that means the mental processes that are just beneath conscious awareness. Some of the more interesting have to do with prejudice, and they are revealed in tests that show how they shape our choices and thoughts. The second meaning derives from psychoanalysis, where it refers to the part of mind that is unavailable to consciousness (2012:45).

This study focuses on the unconscious from psychoanalysis view. From this view, it is seen that the unconscious consists some repressed feelings and ideas from conscious mind. The content of the unconscious usually creates the effect indirectly in our behavior and in mental processes, and the move from unconscious to consciousness often follow the path of displacement (2012: $45)$.

According to Carl Jung's theory about the levels of psyche, there are two levels, the conscious and unconscious level. Conscious images are those portrayed by the ego, which is the core of conscious mind, but not the core of personality. Ego only plays a minor role in analytical psychology study, thus an overemphasis on expanding one's conscious psyche can lead to psychological imbalance (Feist, 2006: 103). Because ego does not represent the whole personality of someone, this conscious level theory by Carl Jung is not the focus of the theory used to analyze this research.

Jung categorizes the unconscious level into two types, which are personal unconscious and collective unconscious. Collective unconscious focuses on the roots in the ancestral part of the whole species, and its physical contents are inherited and passed from one generation to the next generation (Feist, 2006: 104). Because the unconscious theory used in this research only involves the main character of the story, the focus of the unconscious theory is on the personal unconscious. 
In Theories of Personality, it is stated that "the personal unconscious embraces all repressed, forgotten, or subliminally perceived experiences of one particular individual. It contains repressed infantile memories and impulses, forgotten events, and experiences originally perceived below the threshold of our consciousness" (Feist, 2006: 104). Human being must have faced a lot of experiences since they were born until they become adult, and each human faces different experiences. Personal unconscious is shaped by each person's individual experiences, and therefore each person is unique. However, the images in the personal unconscious have different difficulty to be recalled, some can be done easily, some are remembered with difficulty, and some others are beyond the memory (Feist, 2006: 104).

\section{Decision Making}

Making decisions is done by people all the time, knowingly or unknowingly. The study of decisions consists of normative and descriptive models. "The normative analysis is concerned with the nature of rationality and the logic of decision making, while the descriptive analysis is concerned with people's beliefs and preferences as they are, not as they should be" (Kahneman, 1984: 341).

These models are described more clearly in an article entitled Designing for Decision Making by David H. Jonassen. He also divides decision making theory described in the literature into two distinct conceptions, which are normative or prescriptive models and descriptive or naturalistic models. "Normative theories of decision making assume that decision makers are rational people who seek to identify the optimal decision choice that maximizes utility in any uncertain situation. Based on norms or standards of how decision making should be done, normative theories often prescribe how people should make decisions in the form of directives or rules" (Jonassen, 2012: 343).

On the contrary of normative concept, descriptive model of decision making are based on research that examines how people actually make decisions. People barely use the rational thought as what normative models assume. "Rather, decisions are often made or influenced by unconscious drives and emotions as well as previous experiences. Additionally, personal identities play a significant role in decision making" (Jonassen, 2012: 343-344). People seldom have the quantitive comparing options, they frequently consider the possible outcomes and the effects in the future of that decision-making they have done. Besides, decisions are also often influenced by each individual identity and the social expectations connected to that identity (Jonassen, 2012: 344).

Descriptive decision making is the concern of this study. However, a question must appear "If people are not rational, how do they make decisions?". This descriptive model is the answer because its approaches focuses on the roles of identity and unconscious emotions in decision making (Jonassen, 2012: 348).

\section{Mia Hall in If I Saty}

\section{Family-Centered}

In the beginning of the story, when her parents want to use the day-off to visit Henry and Willow, their close friends, Mia hesitates to join. She prefers to go back to bed. However, when his father mentions that they can also visit her grandparents for having an early dinner on their way back home, she directly says, "I'm in" (Forman, 2010: 10). She loves being together with her family, and it is shown in her monologue: It isn't the lure of Book Barn, or the fact that Adam is on tour, or that my best friend, Kim, is busy doing the yearbook stuff. It isn't even that my cello is at school or that I could stay home and watch TV or sleep. I'd actually rather go off with my family (Forman, 2010:10). That statement shows that Mia agrees to go not because of the lure to a bookshop or that her best friend and boyfriend are busy, but because she 
prioritizes her family over anything else. This part of story is still in the beginning before they get the accident. In this part, the author uses the showing way to present the readers about the family-centered characteristic in Mia Hall.

Both when she is alive and when she is in the comatose state, Mia Hall is familycentered because of her focus and love is first to her family members. Firstly, this part shows how deep her love is to her parents. The first evidence is seen from the way she remembers her parents. She tells about how her parents never call Teddy and her as accidents, surprises, nor any other calling; how her parents appreciate every process that they have while being with her and Teddy (Forman, 2010: 85). The acceptance that her parents do for their children makes Mia love her parents very much.

Then, after her family gets the accident and her parents do not survive, when she is in the comatose state, she feels empty and frustrated to face this state because her parents are not there for her.

My parents aren't here. They are not holding my hand, or cheering me on. I know them well enough to know that if they could, they would (Forman, 2010: 87). How am I supposed to decide this? How can I possibly stay without Mom and Dad? How can I leave without Teddy? (Forman, 2010: 88)

Besides being family-centered to her parents, Mia Hall also cares about her younger brother, Teddy. When the car accident happens, and her soul wakes up, the first thought appearing in her mind is to find Teddy. "'I need to find Teddy! Where is he?" I spin around, suddenly frantic, like the time I lost him for ten minutes at grocery store" (Forman, 2010: 17). She shows her love to Teddy through her actions. When Teddy cannot survive, she feels mournful. It is really painful for her to accept the reality that her little brother does not survive.

I run away.

I leave Adam, Kim, and Willow and I just start careening through the hospital. I don't realize I'm looking for the pediatric ward until I get there (Forman, 2010: 159).

I'm looking for him, even though I know I won't find him. Still, I have to keep looking (Forman, 2010: 160).

\section{Enthusiastic}

Mia Hall is an enthusiastic person, especially when it deals with music. It can be seen from her big ambition to be a professional cellist. She starts playing cello when she is eight years old, and she has her first recital 2 years after she starts practicing, which is 10 years old. The researcher states that Mia Hall is an enthusiast because she performs in a recital only with a 2-year learning period and when she is still very young. At first, her parents also do not believe in their daughter's enthusiasm.

When I announced to Mom and Dad that I was going to become a cellist, they both burst out laughing. They apologized about it later, claiming that the image of pint-size me with such a hulking instrument between my spindly legs had made them crack up. Once they'd realized I was serious, they immediately swallowed their giggles and put on supportive faces (Forman, 2010: 22).

That quotation shows that her parents are surprised when they know how their daughter is really high-spirited in reaching her dream. She is only ten years old at that time, and she already decides that she is going to be a cellist in the future. Since then, her parents always support her ambition to be a cellist. They hire a cello teacher for Mia Hall. Her name is Professor Christie. It is Mia's father who knows her, and she wants to listen to Mia's play first. After she does it, she offers to take over the training (Forman, 2010: 24).

When she grows up and she is in the third grade of senior high school, it is the moment when she has to choose where to 
continue her study to the college. When her grandmother gives an idea about her enrolling to Julliard, the most popular university for art, she is very excited. When her parents also support her, she fills out her application and sends in a recording of her playing (Forman, 2010: 46-48). Few days after sending it, The Julliard School sends her an invitation letter to an audition held in San Fransisco. By directly sending her application to Julliard, it shows how enthusiastic Mia Hall is.

However, she does not directly tell Adam about applying to Julliard because she thinks that by telling Adam, she might not enroll there and pursue her ambition because then they will be distant. It is stated in So, I filled out my application, collected my letters of recommendation, and sent in a recording of my playing. I didn't tell Adam about any of this. .... A small part of me felt like applying was some kind of betrayal. Julliard was in New York. Adam was here (Forman, 2010: 48).

After Mia gets the invitation letter from Julliard, she tells Adam about her enrolling there. Mia Hall is a family-centered person, and she also feels sad to choose Julliard at first because she has to be far away from her parents too. However, because her parents always support her to reach her dream, she can be relieved to leave them. Adam, Mia Hall's boyfriend, also supports her, but Mia Hall does not directly tell Adam the truth because she does not know what will happen to them in the future if they are apart.

When Adam and Mia goes to a New Year's Eve party, they have a discussion about their going-to-be long distance relationship, and Mia becomes thoughtful about what Adam says to her, "Promise me you'll spend New Year's with me next year" (Forman, 2010: 207). After that party, Mia goes home and her expression is different. Her mom turns to her and she directly cries and releases all of the tension with her mom.

Mom shot me a sympathetic grimace. "I don't know. But I do know that if you want to stay and be with him, I'd support that, though maybe I'm only saying that because I don't think you'd be able to turn down Julliard" (Forman, 2010: 211).

Relating this trait to the plot development, in the end of the story, when her family creates a family gathering and when everyone asks Mia and Adam to play the music together, Mia plays cello and Adam plays guitar, she keeps refusing because she insists that those two styles do not fit together (Forman, 2010: 226). Although both of them play strings musical instruments, both of their styles are different. Mia prefers classic genre, while Adam always plays rock music. That is why, Mia is not confident if her enthusiasm in music can be shown well when she plays it together with Adam.

I was a little scared of falling on my face, ofnot blending, of making bad music. But everyone was looking at me so intently, wanting me join in so much, and I realized that sounding bad wasn't the worst thing in the world that could happen. So I played. And even though you wouldn't think it, the cello didn't sound half bad with all those guitars. In fact, it sounded pretty amazing (Forman, 2010: 227)

There is a development of enthusiastic trait in this part of story. When it comes to music, she is always enthusiastic for herself before, but after she remembers this event, her enthusiasm in music is not only for herself, but also for others.

\section{Loving}

Mia is a loving person. She loves and cares about her family; Kim, her best friend; and Adam, her lover; and all of them also love her very much. When the plot is in Mia's life before accident, it can be seen that Mia tries to fit in Adam's life even though she does not like and enjoy it. When Adam invites her to his band play, this is what Mia Hall thinks 
Adam invited me to see his band play. This was even worse than school. If I felt like a fish out of water in my family, I felt like fish on Mars in Adam's circle. He was always surrounded by funky, lively people, by cute girls with dyed hair and piercings, by aloof guys who perked up when Adam rock-talked with them (Forman, 2010: 55).

Although Mia Hall says that she feels like a fish on Mars in Adam's circle, she comes to Adam's band play every time he invites her. She keeps supporting Adam in his career with the band. She struggles to hold herself from the situation around her so that she still can be there for Adam when he performs. The author uses the showing method to show this loving trait that Mia gives to Adam.

When Mia is in the comatose state, the person she wants to see most is Adam. For this plot development, the author uses the telling method to show how big Mia's desire is to meet her most beloved one. She says,

Adam is the one I really want to see. I wish I knew where he was so I could try to go there. I have no idea how he's going to find out about me. Gran and Gramps don't have his phone number, so he can't call them. They don't carry cell phones, so he can't call them (Forman, 2010: 53).

When her body is in comatose, and her soul is observing people around her, Mia Hall really expects Adam to be there. She thinks about the ways how to contact him, but she certainly cannot do that by herself.

When Adam arrives at the hospital, he cannot directly see Mia because she is in the ICU and it is only her immediate family members who are allowed to see her (Forman, 2010: 107). When Kim asks him to give up seeing Mia, he does not want to. He says, "I only need a second. So I can show her that I'm here. That someone's still here" (Forman, 2010: 125). By saying that, Adam shows that he wants to fight for Mia. He does not want Mia to give up because for at least
Mia has someone who is there for her. $\mathrm{He}$ has sacrificed his band performance, which is actually on that night. If Mia is not a loving person, Adam may not want to struggle like that. After Adam finally succeeds to see her, Mia feels so happy until she wants to be one with her body so that she can feel the love directly from Adam's hand (Forman, 2010: 197-198).

Besides loving Adam, Mia also loves Kim very much. Kim is her best friend in the school. Mia Hall and Kim have been friends since they are in the six grades. At first everyone says that they will get along as close friends. However, they resent one another, and they have an actual fight. By the end of the fight, they laugh and become friends just like everyone has predicted. From that point on, they are inseparable (Forman, 2010: 71-73). When Kim arrives at the hospital, she feels very happy. It is stated that

I'm so happy when Kim arrives; happy to see the familiar sight of her long black hair in a single braid. She wears the braid every day and always, by lunchtime, the curls and ringlets of her thick mane have managed to escape in rebellious little tendrils (Forman, 2010: 63).

Mia pays attention to every single thing which Kim is wearing at that time. By showing that Mia is a caring person, the author wants to convey that Mia is a loving person. Mia Hall always appreciates her friendship journey with Kim. It is stated that "When we got older, we liked to joke that we were so glad we had that fistfight. Not only did it cement our friendship but it also provided us our first and likely only opportunity for a good brawl" (Forman, 2010: 74).

When they are nostalgic about the beginning of their friendship, they always laugh at it. However, when Mia is in the comatose state and almost decides to leave the world, she shows a deep sadness if she should leave her best friend.

I know that Kim's telling me this to try to 
keep me alive. She probably doesn't realize that in a weird way, her remark frees me, just like Gramp's permission did. I know it will be awful for Kim when I die, but I also think about what she said, about not being scared, about jail being easy compared to losing me. And that's how I know that Kim will be okay (Forman, 2010: 218).

In the plot development, this quote is almost reaching the end of the story. It means that Mia is in the critical state when she says this in her mind. She is in the moment where she has to choose between to stay or to leave. However, she still thinks about Kim's feeling at that time. She knows that Kim will be awful if she chooses to leave the world, but she also believes that Kim will be okay about any decision she is going to take. In this part of the story, the author shows the loving characteristic of Mia Hall by the telling method, which is by her own utterances.

\section{Thoughtful}

She does not decide something easily, she always considers everything well, and she also thinks about other people's wishes and feelings. When Mia's Gran and Gramps just finish visiting her room, they talk about unexpected conversation about Mia, and Mia hears it. The conversation starts from a question by Gramps, "Do you think she decides?” (Forman, 2010: 86-87).

After Mia listens to that conversation, then she becomes considerate about the comatose state she is having.

If I stay. If I live. It's up to me. All this business about medically induced comas is just doctor talk. It's not up to the doctors. It's not up to the absentee angels. It's not even up to God who, if He exists, is nowhere around right now. It's up to me. How am I supposed to decide this? How can I possibly stay without Mom and Dad? How can I leave without Teddy? Or Adam? This is too much. I don't even understand how it all works, why I'm here in the state that I'm in or how to get out of it if I wanted to. But in spite of that, I believe it's true. I hear the nurse's words again. I am running the show. Everyone is waiting on me. I decide. I know this now. And this terrifies me more than anything else that has happened today (Forman, 2010: 88).

When she tries to think about how she can make a decision in that comatose state, she cannot decide directly, she considers many things. She does not want to live without her parents, but she also does not want to leave Adam. It is difficult for her to choose life because she does not have any family anymore. But her love to Adam is also very deep that she cannot leave him and choose to leave the world.

\section{Mia Hall's Decision Making Process}

Mia Hall and all of her family members get a car accident on a snowy day, when the schools are off and her family is planning to visit her parents' friends. However, when they are still on their way to their destination, their car gets crashed by a fourton pick-up truck. The car is totally damaged, looking like a metal skeleton, without any seats, and without passengers (Forman, 2010: 15). The moment after that accident, Mia wakes up. She directly gives her effort to find her family members. Mia's father and mother pass away right after the accident. After she finds out her parents' dead body, she directly looks for Teddy's body. She finds a body near the ditch where she wakes up. She thinks it is Teddy's body. When she edges closer, she realizes that it is not Teddy lying there, but it is herself. She sees how bad her body condition is. She spins away, tries to reassure herself that it is a nightmare. She cannot believe that an accident just happens to her family (Forman, 2010: 15-18).

Mia Hall is in a comatose state. Based on the definition terms mentioned in the previous chapter, a comatose state is a state of extended unconsciousness which is caused by various problems, such as traumatic head injury, stroke, brain tumor, etc. The accident which Mia gets with her 
family causes her to be in a comatose state. However, in the story, her soul is described to be alive, where she can observe the people visiting her in the hospital and the situation around her. As time goes by, Mia Hall realizes that she is the one who can overcome her comatose state if she wants to stay and be alive.

The author, Gayle Forman, puts the main character into a difficult situation, which is in a comatose state where no one around her can see and listen to her directly. The researcher finds that although Mia Hall is in the comatose state, she is showing her struggle to overcome this state through her decision making process whether to stay or to leave.

In this part, the researcher shows Mia Hall's decision making process. The decision made by Mia Hall is that she chooses to be alive and stay in the world. As the title of the novel, If I Stay, Mia Hall has two choices. She is able to choose whether to follow her family members' path or not to follow them by staying and continuing her life without them. The decision making process of Mia Hall is very important to be analyzed because her being coma and her decision either to stay or to leave are the main conflicts in the plot development of the story.

In the accident, Mia is the only one who survives, but she is in the comatose state. Although her body is in a coma, Mia is described by the author to be able to feel and speak to the people surrounding her. However, they cannot respond to her. Mia's soul is described by the researcher as her unconscious mind. According to Jonassen, someone's unconscious mind is able to affect the decision making because decisions are based on values, in which values are related to someone's emotions and choices.

The decision making process by Mia Hall does not take an easy and a short process because during the moments of her unconscious state, there are some matters that she considers. Those matters are the people (her grandparents, boyfriend, and best friend) who keep supporting her and her dream to study in Julliard and also to be a professional cellist. In the previous part of this chapter, Mia Hall's characteristics are analyzed by the researcher. Mia Hall is a family- centered, enthusiastic, loving, and thoughtful person. Relating the unconscious mind to her decision making to be alive, the researcher analyzes that the traits of Mia Hall are able to influence Mia Hall's decision making process in her comatose state and to choose to be alive.

Mia Hall's decision making process is based on the descriptive model. Based on the researcher's analysis, Mia Hall does not decide to be alive by using the rationality and logical mind of a human being. Stated in many scenes of the novel, she loves her parents and her brother very much. In the novel, Mia says, "My parents aren't here. They are not holding my hand, or cheering me on. How am I supposed to decide this? How am I possibly stay without Mom and Dad?" (Forman, 2010: 87-88).

She is unsure if she has to choose to stay without her parents accompany her. She is also frustrated when she knows that Teddy, her beloved brother, does not survive. It is stated on page 159 when Mia says, "I know that all the magic kisses couldn't have helped him today. But I would do anything to have been able to give him one." Mia Hall faces a deep misery because Teddy leaves her after his being in a coma, and it means that she loses all of the beloved members of her family. Because she loves her parents and Teddy very much and she feels alone to live without them, she will choose to leave the world and follow their paths if she uses her logical mind as a human being. However, she does not choose that decision because she does not make the decision using the normative method of decision making, but the descriptive method.

According to David H. Jonassen, decisions, which are based on the descriptive concept, are often influenced by unconscious drives, emotions, and personal identities (2012: 334). The researcher 
applies that theory because those three elements are related to each other in revealing the decision making process by Mia Hall. Mia's personal identities are seen through her characteristics, while unconscious drives and emotions are seen through the action and the speech of Mia's soul.

There are two things discussed by Jonassen when it comes to the descriptive model of decision making, which are the identity-based decision making and the effects of unconscious. There are three questions asked by someone who does the descriptive model of decision making. The first question is "What kind of situation is this?". The second one is "What kind of person am I?". The first and second questions are discussed in the first part, identity-based decision making; and because the third question is related to the unconscious mind of the main character, the question "What does a person such as I do?" is discussed in the second part as the transition to the effects of unconscious.

\section{Identity-based Decision Making}

According to Jonassen, most of the time people make decisions based on rules following identities. In the decision-making process, "people are influenced significantly by questioning their personal identities (2012: 348). In this process, people may ask some questions to themselves, the same as Mia Hall. When she understands that she is the one who decides her own path, she comes to this process. She asks herself the questions: "What kind of situation is this?" to have the recognition and "What kind of person I am?" to reflect on her identity and to use it as her motivation to do the decisionmaking process.

She asks the first question to herself when she is in the location of the accident and when she is in the hospital. When she just gets the accident, she observes the surrounding around her. It is stated that "And there was so much noise... Then, it went quiet, except for this: Beethoven's Cello Sonata no. 3 , still playing. I climb up the embankment to get a better look at the car. It isn't even a car anymore. It's a metal skeleton, without seats, without passengers" (Forman, 2010: 15-16). After observing the audio and visual around her, she notices that her family gets a serious accident until the car is damaged and all of her family members are not inside the car. She also observes what state she is in when the ambulance comes to pick her and her family. It is stated,

"I don't feel anything, at least the me who's a bystander here does not. And the me on the stretcher doesn't seem to feel anything, either. Again, I have to wonder if I'm dead but then I tell myself no... Also, if I were dead, I like to think Mom and Dad would've come for me by now" (Forman, 2010: 30).

She questions whether she is dead or not because she cannot feel anything and she thinks that her body which is on the stretcher also does not feel anything. When she is already in the hospital, she also asks the same question.

The operation goes on and on. I'm exhausted by it... I start to zone out. And then I start to wonder about this state I'm in. If I'm not dead - and the heart monitor is bleeping along, so I assume I'm not - in my body, either, can I go anywhere? Am I a ghost? Could I transport myself to a beach in Hawaii? Can I pop over to Carniege Hall in New York City? Can I got to Teddy? (Forman, 2010: 43)

The second question, which is what kind of person Mia Hall is, is already answered in the previous part of this chapter. As the researcher observes Mia Hall's thoughts, speeches, actions, and how the others respond to Mia, Mia Hall is someone who is family-centered, enthusiastic, loving, and thoughtful. In this identity-based decision making, the theory states that "individuals tend to use rules of behavior from those surrounding them to predict their behavior and decision-making tendencies" (Jonassen, 2012: 349). Before 
Mia is in the comatose state, Mia already has those traits mentioned in herself. When she is in a coma, she tends to see the people surrounding her; her grandparents, her best friend (Kim), and her boyfriend (Adam); to predict whether they want her to fight to live or not. Because they are always there for her and they keep supporting her in her unconscious state, she starts to open herself to realize that she still has many people who love her and she will not be alone if she chooses to stay.

\section{... And Gran would've told me that maybe I was there as an angel before I chose to become Mom and Dad's kid. But now I wonder. And now I hope. Because when I go, I want to remember Kim. And I want to remember Kim. And I want to remember her like this: telling a funny story, fighting with her crazy mom, being cheered on by punkers, rising to the occasion, finding little pockets od strength in herself that she had no idea she possessed. Adam is different story. Remembering Adam would be like losing him all over again, and I'm not sure if I can bear that on top of everything else (Forman, 2010: 217).}

Those statements show that Mia feels difficult to leave her grandparents, Kim, and Adam. She says that she wants to remember them when she leaves the world. However, she wonders and hopes that she does not need to remember them because they are meaningful to her and she cannot bear the pain to lose them, especially Adam, her lover.

The personal unconscious theory by Carl Jung states that "the personal unconscious embraces all repressed, forgotten, subliminally perceived experiences of one particular individual". The following statement is that the personal unconscious contains the repressed memories and the strong wish, forgotten incidents, and experiences seen below the life period of someone's unconsciousness (Feist, 2006: 104). That statement helps the researcher reveal Mia Hall's struggle which is influenced by her characteristics in which her traits are the repressed and perceived experiences that she gets when she has not been in the comatose state. The second question of the identity-based decision making process is "What kind of person I am?", and the characteristics of Mia Hall are able to relate the question to her struggle to overcome her comatose state and to make a decision to stay. As it is described in the previous part of this chapter, the characteristics of Mia Hall are familycentered, enthusiastic, loving, and thoughtful.

Her first struggle is influenced by her family-centered and loving traits. Although her parents and Teddy have passed away and left her, she still has other family members who encourage her to struggle. They are her Gran and Gramps. Her Gran and Gramps are always in the hospital. They never leave Mia, and they always check on the progress of Mia Hall's body. Because Mia Hall is a family- centered person and she does not have her parents beside her anymore, she relies her life on her grandparents.

There is a moment when her grandparents leave her for a moment and she feels uncomfortable. It states that "I am a little freaked out right now. Gran and Gramps left a while ago, but I stayed behind here in the ICU. I am sitting in one the chairs, going over conversation which was very nice and normal and nondisturbing, until they left" (Forman, 2010: 86). The statement clarifies the characteristics of Mia's being family-centered because she always wants her grandparents to stay beside her body, and she enjoys listening to their conversation as if everything is in the normal condition before she is in a coma.

After Mia Halls listens to the conversation between her grandparents and the nurse that she is the one running the show and she is the one who decides, she becomes confused about what to choose. When the plot development is almost reaching the end, her Gramps comes to the ICU and talks to Mia Hall's body. At that time, Mia is already frustrated by the situation 
because she just hears the news about Teddy's not surviving, so she stays inside the ICU, beside her body, and listens to what her Gramps says to her

"It's okay," he tells me. If you want to go. Everyone wants you to stay. I want you to stay more than I've ever wanted a thing in life." His voice cracks with emotion. He stops, clears his throat, takes a breath, and continues. "But that's what I want and I could see why it might not be what you want. So I just wanted to tell you that I understand if you go. It's okay if you have to leave us. It's okay if you want to stop fighting." (Forman, 2010: 181)

Mia Hall's Gramps gives her permission to go. He knows that it is difficult for Mia Hall to accept the truth that her parents and her beloved brother cannot survive, so he says it is okay if Mia wants to choose to die and follow her family. After Mia listens to her Gramps' words for her, her response is

For the first time since I realized that Teddy was gone, too, I feel something unclench. I feel myself breath.... this is the first time today that anyone acknowledged what I have lost ... Gramp's recognition, and the permission he just offered me - it feels like a gift (Forman, 2010: 181- 182).

In one way, Mia feels relieved and glad because she has someone who understands the lost that she feels. Her Gramps also tells Mia that she may choose her parents and Teddy, instead of choosing the life. However, Mia can also acknowledge the sincere love from her Gramps. When her Gramps gives her permission to go, it means that he does not want to be egoistic. He gives Mia the right to decide what she wants to choose although what he actually really wants is that Mia to stay.

Besides the characteristics of being family-centered, Mia Hall is also a loving person. Kim, her best friend, also comes and stays in the hospital. She keeps waiting for her turn to see Mia directly. Before she has the chance to enter the ICU, she goes to a small chapel in the hospital's basement. Mia follows her and sits on a chair beside her. By being together with her best friend, she feels calm. The calm feeling is stated in "It feels so natural the way that Kim is talking to me like she always does. Other than the paramedic who told me to hang in there and the nurse who keeps asking me how I'm doing, no one has talked to me since the accident. They talked about me" (Forman, 2010: 67).

When Mia is with Kim, she feels that Kim is the only one who talks to her and understands her. The way how the nurses take care of Mia is different from the way how Kim cares about Mia. Because Kim is Mia's best friend and she knows Mia very well, the way she talks to Mia is so natural, and Mia feels comfortable with it. In almost the end of the story, Kim is also the one who encourages Mia to stay. She lists all the people who are and have been at the hospital, and she ends her talk with Mia by kissing Mia's forehead and whispering "You still have a family" (Forman, 2010: 219-220).

Mia's other characteristics which give big impact to her struggle are her enthusiastic and thoughtful traits. In the end of the story, when Mia is in the moment where she has to choose, Adam places headphones on Mia's ears and plays YoYo Ma's Andante con moto e poco, her favorite cello music. Adam knows that Mia is very enthusiastic when it comes to music, and music can always make Mia feel alive, so Adam plays the music for the purpose of reminding Mia about her dream to be a cellist (Forman, 2010: 231-233). Mia has already dreamed to be a cellist since she is 10 years old. She also has applied to continue her higher education to Julliard, and she is accepted. Her step to reach her dream is already really close. Thus, Adam plays the music to remind Mia of her dream she can pursue if she chooses to stay.

Mia's thoughtful characteristic is seen clearly when the music is played on her ears. She flashes back everything that has happened in her whole life, and she also imagines what will happen in the future. She remembers her family members, who sit 
around the breakfast table together while the snow is blowing outside; Kim, who will walk through New York City together after they graduate; Teddy, who sits on her lap and is laughing hard; her cello, which is the one her parents gives her after her first recital; and Adam, who is holding her hand and playing the music for her (Forman, 2010: 232). She has many thoughts in her mind. If she is not a considerate person, she will not think about too many considerations. She will directly decides based on the main trait she has, which is the family-centered trait. However, she keeps considering what she should choose, whether to stay or to leave, and in the end, she chooses to stay. After Adam successfully triggers Mia's enthusiastic and thoughtful traits by playing her favorite cello music, the statement below is the struggle which Mia makes in her comatose state to choose to be alive.

Adam is crying and somewhere inside of me I am crying, too, because I'm feeling things at last. I'm feeling not just the physical pain, but all that I have lost, and it is profound and catastrophic and will leave a crater in me that nothing will ever fill. But I'm also feeling all that I have in my life, which includes what I have lost, as well as the great unknown of what life might still bring me. ... The only way to survive them is to concentrate on Adam's hand. Grasping mine (Forman, 2010: 233).

The statement shows that Mia wants to survive. Although she is feeling painful because of her family members she has lost, she wants to take the hopes of life that she still has. She struggles and tries to overcome her comatose state by concentrating on her energy to hold Adam's hand. However, she does not succeed easily, so she does another effort.

I aim every remaining ounce of energy into my right hand. I'm weak, and this is so hard. It's the hardest thing I will ever have to do. I summon all the love I have ever felt, I summon all the strength that Gran and Gramps and Kim and the nurses and Willow have given me. I summon all the breath that Mom, Dad, and Teddy would fill me with if they could. I summon all my own strength... I picture my hand stroking Teddy's hair, grasping above my cello, interlaced with Adam's (Forman, 2010: 234).

After Mia Hall tries to summon all the energy she has, her soul is able to be one with the body again, and she successfully overcomes her comatose state. As it is mentioned above, the researcher states that Mia's soul is the representation of her unconscious mind, and the unconscious mind of Mia Hall is represented as her characteristics because her traits are one of the personal unconscious parts. The struggle that Mia Hall does is motivated by the people around her who keeps supporting her to stay. Mia's grandparents, Kim, and Adam motivate Mia to struggle her coma condition by triggering her characteristics which are in her personal unconscious.

The third question in Mia Hall's decision making process is "what does a person such as I do?". This question makes the person consider the rule which follows the choices she/he has. Because the answer of this question is related to the situation or state which Mia Hall is in, the analysis is discussed and elaborated in the next part of the descriptive model of decision-making process, which is the effects of unconscious.

\section{The Effects of the Unconscious}

According to Brooks, "decisions are value-based, where values drive from our emotions and guide our choice" (2001: xi). Jonassen concludes from Brooks' theory that the main drive for a decision-making process is the mind or the unconscious of a person which affects the conscious value judgements involved in decision making (2012: 349). Humans decide every day. When making a decision, there are some considerations, and the considerations are mostly based on the values of the good and bad impact of the decision. Those values are experienced from the decisions taken in the 
past time, so it can create the emotions toward the decisions which will be taken in the future time. The decision taken by Mia Hall is also a value-based decision. Although the decision between choosing life or death is the first kind of decision making which Mia makes, this decision is driven by her emotion and her unconscious mind which are triggered by her traits.

This part is related to the last question from the previous part because the answer of the question "what Mia Hall will do" is also the effect of her unconscious. Being in the unconscious state, her identity is the only key for Mia to help her consider and decide. Before she decides what she will do, she looks again at the values of her life she has gathered.

In the quiet corner of the ICU I start to really think about the bitter things I've managed to ignore so far today. What would it be like if I stay? What would it feel like if I stay? What would it feel like to wake up an orphan? To never smell Dad smoke a pipe? To never read Teddy another chapter of Harry Potter? To stay without them? (Forman, 2010: 164)

Mia Hall is a family-centered person. When she thinks again about her parents and brother who pass away, she feels like she has no one. She feels like it is impossible to stay without having them with her. Her unconscious mind even makes her not care about her body anymore because she says, "I don't know exactly what's happened to me, and for the first time today, I don't really care. I shouldn't have to care. I shouldn't have to work this hard" (Forman, 2010: 174).

However, when she has lost her hope, her Gramps comes to the ICU and cries. Mia Hall is surprised to see her Gramps cry. This can be seen in her monologue, "When I open my eyes, Gramps is there. He's crying. He's not making any noise, but tears are cascading down his cheeks, wetting his entire face. I've never seen anyone cry like this" (Forman, 2010: 181). She can feel her grandparents' love to her, and she realizes that she still has them as her family.

Besides having her grandparents, she also has a best friend who is very loyal to her. Because Mia is a loving person, Kim loves her very much. She does many efforts to convince that Mia's life is very meaningful because she has many people she can rely on. She lists all the people who are at the hospital or who have been by saying

"Your grandparents and aunts, uncles,
and cousins. Adam and Brooke Vega and
the various rabble-rousers who came
with her. Adam's bandmates Mike and
Fitzy and Liz and her girlfriend, Sarah,
all of whom have been downstairs in the
waiting room since they got heaved out
of the ICU. Professor Christie, who drove
down and stayed half the night before
driving back so she could sleep a few
hours and shower and make some
morning appointment she had... And me
and mom. Shoot. I lost count of how
many people that was. But it was a lot"
(Forman, 2010: 220).

By doing this, Kim is triggering Mia's loving trait unconsciously so that she realizes that she can give her affection to many people who care about her like the way Mia cares about Kim as her best friend.

After considering the values of life which are related to her family- centered and loving traits that she has got by observing her surrounding, her unconscious mind affects her to make her decision into an action. Mia Hall is keen on classic music. Her favorite classic musician is Yo Yo Ma. When Adam wants Mia to struggle her comatose state, she plays Yo Yo Ma music on her ears. This way is based on the value-based theory because the value of Mia's favorite music is able to touch her emotion and guide her to remember again her dream, and intrigue her to choose to be alive. Related to her third trait, Mia is a thoughtful person when she already gathers all the choices she has with each consideration. Because identities are socially formed and they have big tendency in decision making, Mia starts to remember 
everyone she loves when that Yo Yo Ma music plays. In her unconscious self, she has four strong traits which give her the reasons to stay: she still has her grandparents as her family, she has her beloved ones (Kim and Adam) whom she can share her love to, and she has a dream to pursue because she is accepted in Julliard. By having those reasons, she has the main drive supporting her struggle to overcome her comatose state and stay alive in the world.

\section{Conclusion}

Relating it to her decision making process, Mia Hall has two choices. In this novel, death and life are presented as choices which Mia Hall has to choose. She can choose to follow her parents' and brother's path to leave the world or to stay and continue her life. In the end of the story, Mia Hall decides to overcome her comatose state and choose to be alive.

Mia Hall's decision making is based on the descriptive model of decision making because the decisions are influenced and made by the unconscious drive and emotions. There are two process of descriptive model of decision making. Identity-based decision making as the first process is analyzed by answering two of the three questions which are about the recognition and identity of the main character. Mia Hall recognizes that she just gets an accident. She keeps questioning whether in this state she is dead or not because she cannot feel anything and the people surrounding her do not respond her. After she recognizes her being in comatose state, she is able to answer the first question.

The second question asking her identity is related to her characteristics which are discussed in the first analysis. She is a kind of person who is family-centered, enthusiastic, loving, and thoughtful. Thus, the comatose situation and those four characteristics of Mia Hall are able to trigger her step of the decision-making process.

The second process is the effects of the unconscious. This process states that decisions are value-based. The values of Mia Hall's are observed through her emotions and unconscious drives. As they are observed, the effects of the unconscious which are related to the traits having been formed in her unconscious mind are able to reveal her decision, and also to show the reasons why she decides to struggle in her comatose state and choose to stay alive.

The decision making of Mia Hall in which she chooses to stay instead of leaving is considered a unique decision. The process how she makes her decision is supported by the people who care about her. Thus, they also become the reasons why Mia chooses to be alive because she still has some family members, her grandfather and grandmother, who love her very much (family-centered); she has a big opportunity to pursue her dream to be a cellist because she is already accepted in a popular music and art school (enthusiastic and thoughtful); and she still has her beloved best friend and boyfriend who never stop convincing her that she has many people whom she can share her affection with (loving).

The final remark of this undergraduate study is that someone's decision making process is influenced and motivated by the unconscious mind because everything that has been recorded during someone's life is giving impact to what she/he does and decides. As it is seen in the main character of If I Stay, the decision making process done by Mia Hall is influenced by her characteristics and her surroundings which have been formed in her unconscious mind before she is in the comatose state.

\section{References}

Abrams, M. H. A Glossary of Literary Terms. New York: Holt, Rineheart, Winston, Inc., 1981.

\author{
Barry, Peter. Beginning Theory: An \\ Introduction to Literary and Cultural
}


Theory. Manchester: Manchester University Press, 2002.

Brooks, D. The Social Animal: The Hidden Sources of Love, Character, and Achievement. New York: Random House, 2011.

Dastmard, Farzaneh, Tooran Razmjoo, and Vali Salehi. "The Relationship between Psychology and Literature". Journal of Basic and Applied Scientific Research (2012): p. 9420. (www.textroad.com). October 6, 2016.

Dobie, Ann B. Theory into Practice: An Introduction to Literary Criticism. Boston: Wadsworth Cengage Learning, 2012.

Feist, Jess and Gregory J. Feist. Theories of Personality. New York: McGraw-Hill Education, 2006.

Felman, Shoshana. "To Open the Question Literature and Psychoanalysis." The Question of Reading Otherwise. No. 55/56. (1977) p. 5-10. Yale University Press.

(http://www.jstor.org/stable/293043 3). November 1, 2016.

Forman, Gayle. "13 Things You Might Not Know About Gayle". n.p.. n.d.. (http://gayleforman.com/bio/). September 1, 2016.

Forman, Gayle. If I Stay. New York: Penguin Group, 2010.

"Gayle Forman". (http://www.goodreads.com/author/s how/295178.Gayle_Forman). January 13, 2017.

“Gayle Forman's New York Times Bestselling Novel If I Stay Hits Theaters August 22, 2014". Penguin for Every Reader. n.p. July 21, 2014. (http://www.penguin.com/newsroom /gayle-formans-new-york-timesbestselling-novel-stay-hits-theatersaugust-22-2014/). September 1, 2016.
Gill, Richard. Mastering English Literature. London: Macmillan Press LTD, 1995.

If I Stay Summary \& Study Guide Description. If I Stay Summary \& Study Guide. Bookrags. (http://www.bookrags.com/studyguid e-if-i-stay/\#gsc.tab=0). June 9, 2016.

Jonassen, David H. "Designing for Decision Making”. Educational Technological Research and Development. Vol. 60, No. 2 (April 2012): p. 341-359. Springer. (http://www.jstor.org/stable/414885 86). October 3, 2016.

Kahneman, Daniel and Amos Tversky. "Choices, Values, and Frames." American Psychologist. Vol. 39. No. 4 (April 1984): p 341-350. American Psychological Association, Inc. (http://web.missouri.edu/ segerti/ca pstone/choicesvalues.pdf). September 11, 2016.

Kahneman, Daniel and Amos Tversky. Choices, Values, and Frames. New York: Cambridge University Press and The Russell Sage Foundation, 2000.

Kuwahara, Kuldip Kaur. Jung's “Collective Unconscious" Literature, and Cultural Studies, in a Colonial/Postcolonial Context. Jungian Society for Scholarly Studies. Alkahest Designs. n.d.. (http://jungiansociety.org/index.php/j ung-s-collective-unconsciousliterature-and-cultural-studies-in-acolonial-postcolonial-context). September 29, 2016.

Laureys, Steven. "Death, Unconsciousness, and the Brain." Science and Society. Vol. 6. No. 11 (2005): p. 899-909. Natural Reviews, Neuroscience. (http://www.coma.ulg.ac.be/papers/v s/death_unconsciousness_NatureRevN eurosci05.pdf). January 12, 2017.

Mayo Clinic Staff. "Diseases and Conditions: Coma". n.p. August 14, 
2015. (www.mayoclinic.org/diseasesconditions/coma/basics/definition/co n- 20028567). September 1, 2016.

Meliala, Charli Welly Robert S. "Adolescent Risk Taking as Seen in James Joyce's Eveline". Undergraduate Study. Yogyakarta: Sanata Dharma University, 2011.

Pangestuti, Prastika Wigatining. "The Effects of Charley's Dream Toward His Decision Making in Life in Mitch Albom's For One More Day". Undergraduate Study. Yogyakarta: Sanata Dharma University, 2013.

Roberts, Edgar V. and Henry E. Jacobs. Fiction: An Introduction to Reading and Writing. New Jersey: Prentince-Hall, Inc, 1987.

Ryan, Michael. An Introduction to Criticism: Literature, Film, Culture. Oxford: John Wiley \& Sons Ltd, 2012.

Wellek, Rene and Austin Warren. Theory of Literature, New York: Harcourt, Brace and World, Inc, 1962.

Wolterbeek, Elle. "If I Stay.” Journal of Adolescent \& Adult Literacy. Vol. 53. No. 7 (April 2010): p. 616-617. Wiley on behalf of the International Reading Association.

(http://www.jstor.org/stable/256539 18). September 5, 2016. 